\title{
With Changed Market Conditions and Consumer Behavior in the National Economy, How Will the Indian Manufacturing Sector Shape Up in the Post-Corona World?
}

\author{
Kavan Shah, Aisha Tharaney
}

\begin{abstract}
The projected losses that may be borne by the Indian automobile sector in the coming months is nearly Rupees 15,000 crore, rubbing salt in the wounds of an already declining industry. The growth of the Information Technology (IT) and Electronics industry in India has been stunted by the panic and indecision in domestic and global markets, causing losses worth crores for even the biggest tech companies in the country. Manufacturing activity in India has collapsed - with a record-low Purchasing Managers Index (PMI) of 27.4 in April 2020 and only slight improvements since then. It is an indisputable fact that the Novel coronavirus (COVID-19) and its growing spread across India is a massive threat to its manufacturing sector.
\end{abstract}

This research-based essay explores the key changes in the market conditions in the initial months of a 'Post-corona' India and produces solutions and proposals that we believe have the potential to push the manufacturing sector upward and result in national economic growth. Part $I$ of the essay examines the changes in demand and supply patterns and their implications, with focus on the potentially the three most important industries in the Indian manufacturing sector: the automobile industry, the IT and electronics industry, and the pharmaceutical industry. Part II presents original solutions formulated using a variety of factors, conditions and changes in an array of fields and disciplines; microeconomic and macroeconomic factors, potential changes in social behaviour, diplomatic relations, political ideologies, and environmental factors have been analysed to present the proposals with relatively greater merit. All the inferences, predictions, and conclusions in the essay are based on present market conditions, expert opinions, past evidence, anecdotal evidence, and relevant socioeconomic theory.

Index Terms - Demand, Depreciation, Gross Domestic Product, Manufacturing sector, Protectionism, Recession, Supply, Supply Chain.

\section{INTRODUCTION}

Over the last few decades, the manufacturing sector has played a vital role in the overall growth of the country; it accounts for $17 \%$ of the Indian Gross Domestic Product (GDP). The graph below depicts the increasing size of the manufacturing sector although its share in real GDP is gradually decreasing mainly due to the growth and development of the service sector. It has helped create stable employment in the economy, employing more than $15 \%$ of

Kavan Shah, Mumbai, Maharashtra.

Aisha Tharaney, Mumbai, Maharashtra. the national workforce, and has helped promote modernisationand overall prosperity through value addition of raw materials and hence, further research and development.

According to UNIDO, India (with the exception of China) is currently the largest producer of textiles, chemical products, pharmaceuticals, basic metals, general machinery and equipment, and electrical machinery, and India's manufacturing exporters have played a key role in promoting the sector's prowess to consumers across the world. While on one hand sectors such as textiles, and gems and jewelleryhave been India's brand ambassadors in global markets since ancient times, the country has also made its presence felt in key industries such as engineering goods and chemicals.

While an increasing population is boosting demand in the economy, both domestic and foreign investments in the manufacturing sector are on the rise due to initiatives like 'Make in India', and ideologies like 'Aatmanirbhar Bharat', which are allowing for further growth and development. In the coming year, the sector's importance to the domestic and global economy is set to increase even further as a combination of supply-side advantages, policy initiatives, and private sector efforts set India on the path to a global manufacturing hub.

However, the uncertainty brought by the coronavirus pandemic has caused a myriad of pressing issues for the manufacturing sector. The demand for numerous commodities produced by manufacturers has plummeted as the virus has begun spreading in India. Brokerage firm HDFC securities expects revenue of the IT sector to reduce by $2-7 \%$ due to a slowdown in decision making in the next six months while businesses evaluate the impact of the virus that is disrupting the global economy. Moreover, owing to preventive governmental measures, the complete shutdown of factories in a range of industries such as automobiles and textiles is leading to significant shortages in supply.

However, what is interesting to notice is also the effect the Chinese economy is having on Indian manufacturing supply since Chinese factories are also forced to run at very low capacities, Indian imports from China are falling, and this has a direct connection with the increased costs of producers and a falling supply of some manufactured products in domestic markets. For instance, the Indian pharmaceuticals industry has deep links to China, given its reliance on China for critical elements of drug supply chains, and therefore the 
shutdown of chemical plants in China

is causing shortages in our pharmaceutical supplies too. Falling demand and supply are causing a reduction in sales, which in turn causes firms to cut back production and possibly lay off some workers. Moreover, the recently imposed lockdown by the state and central governments have naturally caused absenteeism at work to soar - because while consultants or analysts could work from their homes, it is near impossible for manufacturing workers to continue being productive from their homes. Moreover, the manufacturing sector largely employs workers that are on relatively lower incomes - and the technology and workspace necessary for jobs being completed at home are extremely difficult to obtain - which is causing further increases in unemployment. According to estimates of the Centre for Monitoring Indian Economy (CMIE), unemployment has risen from 8.4 per cent on March 22 to 23.4 per cent as of April 5.

On the contrary, pharmaceutical and other manufacturers of essential commodities are seizing this opportunity as people stockpile food and household itemsand purchase enormous quantities of healthcare commodities. Revenues in such industries are on the rise, and many such businesses are expanding, which does offer some relief.

However, these industries form a very small part of the manufacturing sector and the economy as a whole. The manufacturing sector must be prepared for numerous disincentives, hardships, and operational snags. Both the current situation and forecasts for the near future regarding the manufacturing sector are worrying for the people and the government of India.

\section{METHODOLOGY}

In order to write this study, we conducted secondary research and spoke to experts to gauge their opinion on the potential impacts the Covid crisis could have on the Indian manufacturing sector.

We consulted the following experts:

- Ajeet Khurana (MBA graduate at The University of Texas at Austin)

\section{- Ayan Banerjee (Risk Analyst at Deutsche Bank)}

These expert consultations enabled us to take a detailed and extensive look at existing data, for example, in relation to the automobile industry. Their experiences offered varied perspectives on the pandemic and the staggering effects of the lockdown.

Additionally, we undertook secondary research that critically examined existing literature on different sectors, both domestic and foreign. This research was further developed through several case studies which proved to be a powerful tool to obtain insights and answer the research question. A few of the case studies include: the possibility of Japan funding firms to shift production out of China and into India, the impact on the pharmaceutical industry et cetera. These case studies were finally evaluated to develop predictions and offer suggestions on how to maximise, and expand, the potential of the Indian manufacturing sector.

We have attempted to maintain a non-partisan approach throughout the studyand considered each aspect through multiple perspectives before discussing results and reaching conclusions.

\section{REVIEW OF THE LITERATURE AND DATA ANALYSIS}

While the Novel coronavirus has led to falling stock prices, rising unemployment and a drastic reduction in global trade and interconnectivity, it can be said that the root cause of many of these issues in global and national economies is the change in demand and supply conditions. The Indian manufacturing sector is facing and shall continue to face, a range of problems and roadblocks due to these changes.

Demand is a factor which often determines whether or not something will be produced and sold, and at what price will that something be sold. It is crucial to the success and growth of a firm or an economy - and therefore the demand for manufactured goods and services in India is also extremely important when we examine the effects of the coronavirus on the manufacturing sector as a whole.

Demand for a wide range of manufactured goods has unsurprisingly fallen and is projected to fall in the coming weeks. The panic and uncertainty brought by this pandemic have caused many people to delay their spending on items like a computer, a television, or a new car for that matter. Moreover, lockdowns, halts in production, and shutdown of plants and factories are involuntarily causing demand for goods and services that act as raw materials or that are 'unfinished' for these plants or factories to fall as well.

The automobile industry is the single most important industry in India when it comes to the manufacturing sector. It contributes $7.5 \%$ of India's GDP and $49 \%$ of manufacturing GDP with a large economic multiplier impact. About 35 million Indians, directly or indirectly, are employed by the automobile sector. Unfortunately, and coincidentally, the impact of the Novel coronavirus has been felt most deeply by the automobile sector itself. In fact, the impact is amplified by the fact that the sector was going through a prolonged slump before the arrival of the virus in India. India's growth rate was at a low 5\% in the quarter ending June 2019 - lowest in five years. There was a drop in private investment and a banking crisis that made it difficult to access credit (loans). These factors came together to reduce consumer demand for automobiles. Moreover, due to the transition from Bharat Stage (BS) IV emission standard of cars and vehicles to BS-VI, producers were also forced to align new stocks, which cut production in the short run and further caused the decline of the sector. In the first quarter of the financial year 2019-20, there was a huge decline in the car sales rate which can be accounted to be 23 percent, while passenger vehicle sale rate has nosedived to a mere 18 percent. This is considered to be the worst quarterly performance since the third quarter of the year 2000-01. In the year 2000-2001 the car sale rate graph came down by 27 percent and the passenger vehicle sale rate also declined by 23 percent.

In the current scenario, nevertheless, both demand and supply for automobiles have fallen further, as the hesitance and apprehension due to the pandemic increase, and various sources of supply shortages emerge. At this point, and in the coming weeks, people will be hesitant to travel regularly as lockdowns are imposed in nearly all states across the nation. 
As a result, the usage of automobiles - mainly personal cars, is limited, causing a large percentage fall in demand for personal cars and vehicles. In other words, those who were planning the purchase of a new car will now choose not to do so, and delay their consumption, since they will not be able to drive their car, or for that matter even buy the car - since the car showrooms across numerous cities are closed themselves. That is, if the showrooms are to remain shut for a minimum of one or two more months, it is practically impossible for one to buy a car for those minimum number of days, regardless of the willingness of the consumer. Moreover, with the amount of scepticism in the economy at this moment, very few would consider buying an asset as expensive as a car. "The coronavirus pandemic sweeping the world will turn global economic growth "sharply negative" in 2020, triggering the worst fallout since the 1930s Great Depression," said the head of the International Monetary Fund (IMF). With such statements being made by internationally recognisedorganisations like the $\mathrm{IMF}$, it is fairly straightforward to understand why the confidence in the market would be so low. Several people may fear unemployment, reduction in wages, or fall in business activity in the coming months. With such fears, there will be very few who will purchase a car. Even if a car were being purchased as an investment - acquiring an asset or item with the goal of generating income, most people would rather choose a 'safe haven' or a safe asset such as gold, because while a car may wear away or 'depreciate' over time, thus losing its original value, an asset such as gold is relatively insulated to depreciation and large fluctuations in value.

Moreover, the supply of Indian automobiles has also been forced to take a hit due to the coronavirus, as various roadblocks and impediments for producers have been created. As mentioned previously, a slowdown in the automobile sector was already in action before the pandemic reached India - and this slowdown was caused not only by demand but also by supply. While falling demand over the past few weeks has naturally reduced incentives for automobile producers to keep supplying the same volumes, and thus resulted in shutdowns of various factories and car dealerships across India, the announcement by the Indian government in 2016 about the adoption of BS-VI norms by 2020 was initially one of the chief reasons of decline in production of cars. Producers of automobiles have had to engage in research and developmentand begin stocking up supplies for the production of BS-VI compliant vehicles, and thus production and sales of automobiles have fallen by significant margins. The Indian government is also pushing for a transition to electric vehicles over the next decade, which some experts believe, has further contributed to falling vehicle sales. The novel coronavirus has simply added to the supply-side pressures.

Due to the government-imposed lockdown, automobile manufacturing factories have had to be shut down for about 15-17 days more. Car production has therefore halted and at the moment no new vehicles are being made. All manufacturing workers, managers, supervisors et cetera cannot travel to their workplaces and factories; factories cannot continue to operate. Moreover, this pandemic in India is also leading to various disruptions, between stages of production of automobiles. However, due to lockdowns and curfews in many states, a lot of transportation and logistical difficulties are coming up, making it challenging for materials to reach the Maruti Suzuki plant, and the production chain to continue. This effectively results in a fall in the supply of those Maruti Suzuki cars. Similarly, these impediments are hampering the production and sales of a variety of car manufacturers and resulting in consequential losses, unemployment, and further economic slowdown. Furthermore, the current economic slowdown in China is also having an impact on the production of automobiles in India. China accounts for $27 \%$ of India's automotive part imports and major global auto part makers such as Robert Bosch GmbH, Valeo AS and ZF Friedrichshafen AG have factories located in the Hubei province. Owing to the closure of the factories of these companies, there has reportedly been a delay in the production and delivery of vehicles like BS-IV compliant models - which are essential to keep the automobile sector's head above the water before it begins the production of BS-VI compliant vehicles. Some car manufacturers are relatively more immune to this issue. "The new coronavirus outbreak is unlikely to have a serious impact on India's struggling auto sector even as factories remain shuttered in China as part of an effort to contain the infection", said the chairman of Maruti Suzuki, R.C Bhargava. However, most Maruti Suzuki plants have inventories for up to 30 days, and they do not import many component parts from China, which is the case with a fair number of other producers but may not be the case with all car manufacturers. In the automobile industry, according to data from $\mathrm{ADB}$ and UNCTAD, a report states that in relation to a $2 \%$ slowdown in Chinese production, the Indian industry could be taking a hit of over $\$ 350$ million. This effect is caused because of India's dependency on China for $18 \%$ of its automobile component imports as well as $30 \%$ of its tyre imports. While the sector has enough inventories for the short term, a lack of important components could destroy the Indian automobile sector. Furthermore, if India were to switch its supply channels to countries like Germany and Japan it would be more expensive, at the same time, unable to meet the Indian demand. Moreover, India's automotive hub, Maharashtra has been affected the most in terms of having the largest number of coronavirus cases in India. The automobile sector could face instability for 12-18 months after the lockdown ends, said Ravi Bhatia, president, JATO Dynamics, a global automotive consultancy firm. The consumption of this sector will thus be impacted greatly.

The IT and Electronics sector is also an important part of the Indian manufacturing sector with high prospects of growth in the future. The sector has increased its contribution to India's GDP from $1.2 \%$ in 1998 to $7.7 \%$ in 2017 . The sector aggregated revenues of US\$160 billion in 2017, with export revenue standing at US\$99 billion and domestic revenue at US $\$ 48$ billion, growing by over $13 \%$.

Demand and supply changes are not as consistent as the automobile sector. Due to the coronavirus, the Electronics sector of our economy has been faced with a range of challenges. In this sector, changes in demand patterns are in 


\section{With Changed Market Conditions and Consumer Behavior in the National Economy, How Will the Indian Manufacturing Sector Shape Up in the Post-Corona World?}

fact quite similar to the auto industry, and so are the reasons for these changes. It mainly produces televisions, mobile phones, computers, refrigerators, washing machines, et cetera These products take up a considerable portion of the income of an average Indian citizen. That is, the decision to buy these items is a very important one for ordinary people. At this point, when there is a lot of economic uncertainty, few people have the confidence in their employment, their sources of income, and the economy to make such a decision. People may worry about being laid off or receiving lower incomes and thus may delay the purchase of such electronics even if they may require them at present. Even if they had the willingness to buy such items, lockdowns and curfews in various cities would not permit them to commute to an outlet or store that sold them in the first place - because electronic items are not considered as an essential good or service.

On the contrary, the IT sector comprises software and internet services too, which may not show the same patterns as electronics. As people become homebound across the nation, the usage of streaming services such as Netflix, Amazon Prime and Hotstar is on the rise. These streaming services can be accessed on almost all electronic devices from home itselfand provide a source of entertainment and recreation for individuals and families. The user traffic on Netflix has unsurprisingly hit all-time highs, as it attempts to reduce traffic on telecom networks by 25 per cent while maintaining the quality of service for users in India. Such streaming services also have relatively lower charges when compared to electronic devicesand are within the affordability of most people. For example, while a Netflix standard account costs Rupees 649 per month, the starting price of a Samsung television may be about 40,000 Rupees. Therefore, while demand for electronics is falling, demand for such internet services is increasing by significant margins.

Supply patterns also differ between the IT sector and the Electronics sector. For the latter, supply has taken a severe hit, and one of the chief reasons for this is the Chinese economic slowdown and the shutdown of Chinese plants producing raw materials for Indian manufacturers. In the April-December 2019 period, India imported electronic components worth \$ 4.9 billion and computer hardware imports worth $\$ 3.5$ billion from China. However, this dependency on Chinese exports backfired as the pandemic came into the picture. While some Indian manufacturers will be able to operate from their stockpiles and local suppliers for a few weeks or months, most are simply not able to continue operating for much longer as Chinese plants gradually shut down. "Even those supplies that have already arrived in India require an advanced level of sanitisation before they are allowed to be dispatched to various markets. The tragedy is, no worker is willing to touch any device sourced from China as of now.", says Rajoo Goel, Secretary-General, Electronic Industries Association of India. He adds that the situation is so grave that in next 10-15 days, the industry will be able to utilise only $50 \%$ of new production capacities and in the next three weeks, there is a possibility of a complete lockdown across various manufacturing plants. Problems for the players in the sector are compounded since other countries in the region do not want to fill the gap. "India is unable to import electronics from Japan or Taiwan because these foreign suppliers know the new demand generated as a result of the coronavirus is temporary," says Goel.

The case with regard to the supply of internet and streaming services is potentially more amusing. While the demand for these services has skyrocketed over the past few weeks, providers are facing a glut of content to provide their viewers. Streaming companies like Netflix have built a reputation over the years to bring new content frequently, but at the moment, it cannot do so. The coronavirus is the root cause of this shortage as well; the simple reason as to why new content cannot be put up is the suspension of all production and filming activity across the world. Major productions have been halted and no new content can be created due to lockdowns, curfews and panic among people. Therefore, streaming service providers are fearful that this glut of content, along with the looming threat of a recession ahead, might cause their users to opt themselves out of their streaming subscriptions in the future. However, as of now, while demand is at a high, new content and services are failing to surface. global smartphone production levels are at $16 \%$ which is likely to decline to its 2016 value of $9 \%$. Brands like Oppo and Vivo were expected to double their smartphone production this year, however, the demand is not likely to pick up as India is amidst a production shutdown which could cost this industry up to $\$ 2$ billion. The Indian IT service sectors growth is estimated to plummet by $3-8 \%$ for the next following year due to the coronavirus pandemic. This is due to the delay in customer acquisitions and initiations of new deals. The global tech industry, including India, is heavily reliant on China for designs and the manufacturing of small components, however, the supply chain has been disrupted.

The final manufacturing industry that will be discussed has proved to be one of the most vital industries for India's economic growth and prosperity - the Pharmaceutical industry. India ranks 3rd in the world, in terms of pharmaceutical output volume, and the industry has an estimated annual growth rate of $13 \%$. With the spread of the Novel coronavirus increasing across the nation, the Pharma sector is growing in importance. Be it because of governmental norms, or societal fear, medical items such as masks, sanitizers, and gloves are being widely demanded.

Moreover, coronavirus testing kits and related equipment are also being demanded in bulk by various states in India. Producers are being given incentives to produce more, but the question is can they satisfy the needs and wants of the people? Either way, it is clear that this pandemic has had an impact on the demand and supply conditions of this industry as well. Demand is undoubtedly rising, and investors continue to chase Indian pharma stocks - pushing names like Dr Reddys, Cipla, Divi's Labs, Biocon and Indoco Remedies to their highest levels over the last year. This has happened due to various reasons, which include but are not limited to panic, paranoia, and governmental laws. Panic and the 'herd mentality' are playing a major role in driving demand for medicinal equipment and pharmaceuticals. In the month of March, pharmaceutical sales registered an $8.9 \%$ growth. This was primarily on account of panic buying of medicines in the 
chronic categories. Cardiac therapy drugs saw a $19.8 \%$ growth compared to $11 \%$ in February, anti-diabetic therapy, too, saw a strong growth of $18.2 \%$ in March, compared to $11 \%$ in the previous month.

Moreover, pharmaceuticals and medicinal items do not take a significant proportion of the income of the average Indian citizen. In such extraordinary circumstances, people usually do not hesitate while spending on products such as masks and sanitizers - not only because of their panic but also because these products are relatively inexpensive. The commonly used N95 mask is priced between Rupees 400 to 500, most hand sanitizers are priced between Rupees 50 to 75 and a pair of latex gloves are available at only Rupees 15 . This is not a big purchase for most people, and any fears of unemployment or an economic recession in the future usually would not have a significant effect on the decision to buy such items. Furthermore, irrespective of the willingness to purchase such products, certain state governments have actually declared it mandatory to use some of these while one is outside their homes. For example, in early April, the governments of Maharashtra, Uttar Pradesh, Orissa, Delhi, as well as the Chandigarh Administration made it compulsory to wear masks when outside the house.

While one may say that with such spikes in demand, the pharmaceutical industry is sure to grow by significant margins and make immense progress, there is no certainty to this statement. While demand rises, supply pressures are gradually being built on several pharmaceutical manufacturers. One of the chief causes of these pressures is the shortage of packaging material for various medicinal items - that is being experienced across the country. Even though materials were available to some extent locally, the bulk of the packaging material is sourced from Mumbai for the whole industry across the country and with the lockdown being put into action with full force in the city, pharma companies are finding it difficult to procure it. Vice-Chairman of the Indian Drug Manufacturers Association (IDMA), T Sathish said that they are trying to manage with the available raw material and primary packaging material. However, since pharmaceuticals are listed by the government as an essential service, increased governmental support may be given to these industries. However, the lockdown and curfews are yet again playing a role in the supply chain disruptions, as has been seen in case of both automobiles and electronics. Transportation has become increasingly difficult for Pharma companies, and items like injectable insulin that must be carried under specific conditions simply have no way to reach from one point to another. "This again is another challenge before us. There is no shortage of insulin. This needs to be transported in cold storage and no such facility is available due to the ongoing lockdown. This is the reason why we are insisting upon the functioning of support industry," said IDMA Chairman J Jayaseelan.

To add to the concerns, India's large import dependence on China (nearly $70 \%$ by value) has become a significant threat to India's healthcare manufacturing and global supply chain.

As Chinese manufacturers of pharmaceuticals and drugs continue to operate at low capacities, exports to India have dropped by very significant margins. These exports, which include a variety of organic chemicals and essential pharmaceutical ingredients are causing a large shortage of raw materials for domestic manufacturers. Typically, Indian pharma companies keep inventories of approximately 45 days of the bulk drug required in the formulation. According to data from pharma research firm Aiocd-Awacs, there is adequate stock at distributor level across therapies, with the least in anti-diabetics (four weeks) and highest in dermatology (eight weeks). Overall, there is an inventory of 52 days for antimalarials like hydroxychloroquine (HCQ), despite the spurt in sales. As production and transport ramps up, stock levels are expected to go up and stabilise, preventing any shortages of essential medicines. However, small enterprises would generally face a bigger problem, since their inventories store volumes that are lower than average and are therefore relatively less sustainable. Although Chinese pharmaceutical exports have begun returning a few days ago, supply shortages in China are resulting in these exports being priced at all-time highs barely lifting the burden off these small Indian manufacturers. However, as Chinese imports gradually begin to pick up in terms of volume, the situation may start improving. To add on to that, "Despite the shutdown of various chemical companies in China, which has reduced India's raw material supply, the USA and the European Union will diversify their markets, thus creating a large possibility of business to be diverted to India," said Gautam Duggad, head of research of institutional equities at Motilal Oswal. Indian chemical makers have gained in the range of 2-17 per cent so far this year even as the benchmark Nifty 50 Index tumbled. Parts of India's chemical industry are optimistic about the effects of the virus and have increased their profit margins, allowing them to further boost their manufacturing activities.

\section{RESULTS AND DISCUSSION}

We have considered the numerous ways in which changing market conditions and consumer behaviour has affected and will affect key manufacturing industries of the Indian economy. However, the alarming ramifications described in the predictions that were made can be mitigated by changes in policies and mindsets, and most importantly, leveraging the effects of the pandemic.

China has found itself facing global scrutiny since the then-epidemic, now-pandemic erupted in Wuhan, both for its delay in not alerting the world community about its severity as soon as possible and for admonishing doctors and journalists, who served as harbingers of the pandemic.

As nations such as Europe and North America attempt to support businesses swivelling under the financial burden, they have also become more worried about China-with suspicions surrounding Beijing's trade methods, Chinese intellectual property theft, and worldwide overdependence on Chinese supply chains. Japan, for example, recently declared a $\$ 2$ billion subsidy program to get Japanese companies to relocate production from China to Japan. Earlier this month, the European Union's competition manager, Margrethe Vestager, called on EU countries to consider purchasing 


\section{With Changed Market Conditions and Consumer Behavior in the National Economy, How Will the Indian Manufacturing Sector Shape Up in the Post-Corona World?}

stakes in their businesses to avert the danger of Chinese takeovers.

India is no exception. The Indian government stands staunchly against the lack of Chinese transparency with regard to the pandemic. Moreover, recent skirmishes at the Sino-India border, wherein 20 Indian troops were killed in the crossfire at Ladakh, have accentuated tensions between India and China. A study by the Delhi University psychology faculty shows $56 \%$ of respondents vowing to buy Made-in-India products, while $42 \%$ say they would boycott Chinese goods. This sentiment is prevalent in various parts of India; some regions have even seen protests against products made in China. On April 17th, even before the clash at the border, the government tightened its policy on foreign direct investment (FDI) to require investment from any country that shares a land border with India to go through a government approval process. Since the only neighbour with significant trade flows is China (neighbouring Pakistan and Bangladesh already faced restrictions), the target of the new rule was abundantly clear. But due to increasing tensions recently, India has further amended rules for purchases by government departments, making it mandatory for suppliers to mention the country of origin in a move to push for local products and keep out Chinese manufacturers.

As the globe is looking away from China, it is a gift for India, the Minister of Road and Transport told CNN. "This is the time for India to get into joint ventures with foreign companies," he said. "I am confident that we will get a response from western countries, particularly from the United States, the United Kingdom, Italy and France," he said. "India will be a good destination for foreign investment due to the availability of skilled labour and the low cost of land." Secretary-General of industry body ASSOCHAM, Deepak Sood, said "If India comes out of the present crisis with a minimum of impact, we can be the destination of choice for the global manufacturing giants in different sectors like electronics, computer hardware, pharmaceuticals, including medical devices, automobile, including components and other engineering products."

India is indeed receiving inquiries for investments over the past few weeks - especially in the manufacturing sector. India's expanding economy and robust middle class provides a lucrative market while its abundant skilled and semi-skilled labour adds to the country's ability to support bulk manufacturing, assembly, and processing. Furthermore, India's overlooked eastern coast is strategically placed to connect with Asia-Pacific markets, an advantage to optimize supply chains and minimize transportation costs. In addition, India's cost advantages come alongside its democratic fabric, with an emphasis on transparency and rules-based international order. India's willingness to meet its supplier obligations without weaponizing trade provides the global business community with predictability and fair trade.

A wide range of news articles and experts propose the same broad ideas about how India could leverage the Anti-China sentiment, and in doing so, boost the manufacturing sector. The government of India should adopt a phased strategy, prioritizing several immediate, medium, and long-term components.
In the near term, the government should announce eye-catching schemes to invite companies to manufacture in India's eastern coast and traditional manufacturing clusters. To set the right tone, the government should establish effective communication through business-friendly channels to convey easy availability of land in mega special economic zones (SEZs), ready-to-move-in facilities, sector-specific business-friendly regulations, a simple labour code, tax breaks, and other incentives aimed at bringing its manufacturing competitiveness on par with the most competitive destinations in Asia.

India should aim at targeting low-hanging fruits in the next six-to-eight months, winning major investment deals in sectors where the economy has domestic supply chains. Moving up the value chain is far easier when there is an underlying ecosystem. Targets could include pharmaceuticals, mobile phones, machinery, and other sectors where there is a robust network of small and medium-sized enterprises (SMEs). These rapid early successes will set the momentum in attracting subsequent mega manufacturing investments in other sectors.

Furthermore, Narendra Modi should place a special emphasis on India's commercial diplomacy, expanding diplomatic strength in key missions to engage business leaders with increased vigour. Often, India's commercial offices in prominent missions are understaffed. To this end, the government should enable the lateral entry of some of India's best private sector professionals with sectoral and negotiating expertise into the diplomatic corps. India should have its best commercial diplomats in friendly capitals like Washington, D.C., Tokyo, Seoul, and Singapore and on missions to important commercial cities, including San Francisco and Osaka, to reinforce India's position as the next big manufacturing destination.

Thus, while India focuses on the previously mentioned proposals, the government must also modify the 'Make-in-India' initiative and make it more precise and focused so as to make more tangible economic changes in the manufacturing sector and move towards attaining the goals it initially set. Therefore, it is clear that if the Indian government puts into action such policies, the net Foreign Direct Investment (FDI) in Indian industries and companies is very likely to increase. Moreover, in 2019, India's ease of doing business according to the World Bank report, ranked 77th, among 190 nations. According to the latest report, the country has jumped to the 63rd position. While India's rank has increased significantly over the past few years, if the government further reduces the rules and regulations in relation to setting up a manufacturing business, the make in India plan will prove to be more successful.

A recent economic survey conducted by the government concluded, "Setting up and operating services or manufacturing businesses in India face a maze of laws, rules and regulations." In manufacturing alone, units have to conform with 6,796 compliance items, which is a "tedious and time-consuming task", the survey noted, adding that burdensome documentation must be removed. This is evidence that in a time like the 'Post-corona world', India can adapt to the 'slowed down and set back' economic conditions 
and implement changes in its rules and regulations, use its land and labour more efficiently and emerge as an economic powerhouse, rapidly moving up ranks in the World Bank's report.

Implementing the previously discussed policies, and making business easier and smoother in India, would be extremely helpful in increasing FDIs coming into the nation. If the FDIs do rise, the economy, and the manufacturing sector in specific, will gain numerous advantages over other economies and nations.

Recipient manufacturers get access to the latest financing tools, technologies and operational practices from across the world. Over time, the introduction of newer, enhanced technologies and processes results in their diffusion into the local economy, resulting in enhanced efficiency and effectiveness of the industry. Moreover, production levels may increase due to newer and more efficient technologies, and the average costs of production would naturally decline. Also, by facilitating the entry of foreign organisations into the domestic marketplace, FDI helps create a competitive environment, as well as break domestic monopolies. A healthy competitive environment pushes firms to continuously enhance their processes and product offerings, thereby fostering innovation. Consumers also gain access to a wider range of competitively priced products. Finally, the creation of jobs is the most obvious advantage of FDI. It is also one of the most important reasons due to which the Make in India initiative was launched. The boost to the manufacturing sector due to increased FDI, in turn, would create jobs, and help reduce unemployment among the educated youth - as well as skilled and unskilled labour of India.

Lockdowns, curfews and restrictions have been imposed all across India as the threat of the virus continues to rise. But all this change has also led to some unexpected consequences on the environment. Two perspectives with regard to the post-corona world emerge. The first perspective says that there we will see no sustainable change in national pollution levels once the lockdown is eased. As the virus begins to subside, and life moves towards normalcy, pollution levels will pick up. People will begin returning to work and thus commuting to their workplaces, production in factories would take off, and domestic and international flights would be back in action. As a result, emissions from vehicles and aircraft, waste gases from factories, et cetera would increase and gradually, the environment would be as badly damaged as it was before the coronavirus came into the picture.

However, the other perspective says it may be the case that people who are avoiding travel right now are really appreciating spending time with families and focusing on other parts of life. These moments of crisis can highlight how important those priorities are and help people focus on the health and wellbeing of family, friends and community. Maybe more importantly, the impact of a reduced number of vehicles on the roads reduced production from industries and factories and reduced human presence in the environment in general, is clearly visible. People have seen the distinct impact the coronavirus and the lockdown has had on the environment. And thus this second perspective states that people would prefer keeping this change in nature undisturbed - and therefore would travel and purchase only as much as needed. As a result, production in a range of industries may begin to fall due to falling demand for many commodities like automobiles and electronics in the short run and large stockpiles of such commodities already stored in production units. It can be said that people would look forward to new ways and ideas that minimise the environmental ramifications of daily life in the post-corona world and explore alternatives for the same. This perspective, which may become increasingly common in India, opens up an important area that the manufacturing sector can leverage: Renewable energy.

Recently, even before the arrival of the coronavirus pandemic, India had made meaningful strides in the energy sector - exploring new ways and methods to harness renewable energy. The Indian renewable energy sector is the fourth most attractive renewable energy market in the world. India is ranked fourth in wind power, fifth in solar power and fifth in renewable power installed capacity as of 2018. According to the 2018 Climatescope report, India ranked second among the emerging economies to lead to a transition to clean energy. Installed renewable power generation capacity has increased at a fast pace over the past few years, posting a growth rate of 17.28 per cent between FY14-19.

With the increased support of the government and improved economics, the sector has become attractive from an investor's perspective. As India looks to meet its energy demand on its own, which is expected to reach $15,820 \mathrm{TWh}$ by 2040 renewable energy is set to play an important role. As a part of its Paris Agreement commitments, the Government of India has set an ambitious target of achieving $175 \mathrm{GW}$ of renewable energy capacity by 2022 . These include $100 \mathrm{GW}$ of solar capacity addition and $60 \mathrm{GW}$ of wind power capacity. Government plans to establish a renewable energy capacity of $500 \mathrm{GW}$ by 2030 .

A range of government initiatives has been taken to further boost these manufacturing industries that are producing machinery and component parts to harness renewable energy. A new Hydropower policy for 2018-28 has been drafted for the growth of hydro projects in the country. The government of India has announced plans to implement a US\$ 238 million National Mission on advanced ultra-supercritical technologies for cleaner coal utilisation. The Ministry of New and Renewable Energy (MNRE) has decided to provide custom and excise duty benefits to the solar rooftop sector, which in turn will lower the cost of setting up as well as generate power, thus boosting growth.

However, in the future, renewable energy will not only be demanded due to the new perspective that many will adopt in the post-corona world but also because of the deep hit the oil and gas industry has taken both within and outside India. Perhaps influenced by recent dramatic events, such as the collapse of the crude oil prices to below zero dollars, India scaled back its fossil fuel production.

Over the last 3 months, oil production reached 2.7 million tonnes, while gas production hit 2.4 billion standard cubic metres, figures that are $5.5 \%$ and $8.64 \%$ lower respectively than last year's numbers. Furthermore, the oil production 


\section{With Changed Market Conditions and Consumer Behavior in the National Economy, How Will the Indian Manufacturing Sector Shape Up in the Post-Corona World?}

figure is $13.79 \%$ lower than the country's target for the period, and the country's refinery output, reflecting crude oil processing, rather than extraction, was $5.74 \%$ lower than in March 2019. The news is the latest to reflect struggles in the Indian oil production sector, which saw crude oil production reach an 18-year low earlier this month.

The country produced 32.17 million tonnes of oil in 2019-2020, 6\% lower than the previous year, as doctors' advice to remain indoors and avoid gatherings with other people proved all but incompatible with conventional working practices in the oil and gas industry.

Renewable energy acts as an extremely suitable alternative - and therefore, will be sought by governments and firms across the globe. If India focuses on renewable energy sources and the government spends on improvements in technology and research and development, the changing perspectives and market conditions in the post-corona world will boost this sector and thus the manufacturing sector as a whole.

The coronavirus pandemic is also likely to make the international community prioritise ensuring greater public health for its citizens. In a post-coronavirus global order, India's relative advantage can count heavily on becoming a major provider for the world's public-goods and services i.e. in healthcare and pharmaceuticals. India's standing advantage of large-scale pharmaceutical production enables it to significantly leverage its soft power by capitalizing in the external development of the healthcare sectors of other nations by ramping up exports in pharmaceuticals, becoming a preferred medical tourist destination for those seeking affordable treatment in quality secondary/tertiary health services, and pursuing medical diplomacy by providing medical training and technical expertise to many other developing nations whose healthcare systems are much worse than India.

According to the Indian Brand Equity Foundation (IBEF), pharmaceutical exports of India from the financial year 2012 to 2019 have steadily grown from $\$ 10$ billion to $\$ 19$ billion. As mentioned previously, India ranks $3 \mathrm{rd}$ in the world in terms of pharmaceutical output volume, and the industry has an estimated annual growth rate of $13 \%$. With the threat of the pandemic increasing across the nation and world, both the domestic and the global Pharma sector is growing in importance.

There is, therefore, a much larger potential for India's pharmaceutical sector now to boost trade partners both regionally and in other parts of the world. The government can promote this by investing in more research and development for drug and pharma study within India (public medical colleges and universities can be used for this purpose) and provide for more incentives to the private sector to strengthen its production for export channels.

Made-in-India drugs supplied to the developed economies such as the US, EU and Japan who are known for their security and quality. In recent years, India has seen intensifying competition from China, which it has been able to sway due to its inherent cost advantage, manufacturing intermediates and APIs at a cost much lower than those in India which has resulted in a gradual increase in API imports from China to India and this, in turn, has led to the killing of domestic manufacturing capability for certain key APIs and their advanced intermediates. But with many countries now looking at de-risking their supply chains by moving out partly or wholly from China, Indian pharma companies have a great objective to move in and present themselves as a reasonable alternative. This is a golden opportunity for the pharmaceutical sector in India to grow at unprecedented rates and become a global pharma production hub.

Finally, in the post corona world, one of the most important things to note is going to be the rapid increase in entrepreneurship. The crisis creates opportunities for businesses to become more innovative. Facing external pressures, some business leaders are stepping out of their routines and comfort zones to become creative problem-solvers. Along the way, they rediscover their entrepreneurial spirit. Some will continue to pursue opportunities first identified during the crisis. Perhaps some automotive suppliers will make medical equipment, while service providers integrate new online interfaces with their traditional businesses. Second, reputations are built and lost during times of crises. Companies demonstrating good citizenship by helping with shortages, or by making major donations, are also probably hoping that consumers will remember their actions when the economy returns to normal. On the other hand, there are also a lot of opportunities to ruin a reputation. Companies that treat their employees or customers badly during a crisis will face major challenges rebuilding when the storm has passed. Similarly, if corporate behemoths like Amazon fail to provide reliable logistics solutions to small businesses right now, then others will develop competing platforms. Those new platforms will not only enable buyers and sellers to meet but will also integrate service providers to transport products in a timely and reliable manner. This issue of a reputation being tainted due to lack of adaptability is hence a golden opportunity for new start-ups and businesses to capture markets once the pandemic subsides. Factors such as these are going to provide strong support to entrepreneurs in the post-corona world and this is another potential boost for the manufacturing sector and an area where India should focus.

"Start-ups in the fields of telecom, defence manufacturing, automobile, Internet of Things, financial technology modules and mobile internet have immense potential to succeed in the scheme of 'Make in India'," said Siddhartha Das, general partner, VentureEast addressing aspiring entrepreneurs at the discussion on "Entrepreneurship - Role of Startups towards Make in India".

Ganesh Suryanarayanan, GM, IoT, Cloud and Analytics Solutions, Tata Sons, said that entrepreneurship and startups have become synonymous with e-commerce in the present times and highlighted that encouraging core manufacturing sector entrepreneurship is equally important.

Therefore, increased legal and governmental support to upcoming businesses is very likely to enable further growth of the manufacturing sector in the coming years. The government has, in fact, come up with a number of new programmes and opportunities for bringing out the best in these companies and help them in innovation and 
development. Launched in 2016, the Startup India initiative promotes and assists entrepreneurship by mentoring, nurturing and facilitating startups throughout their life cycle. Apart from the scheme 'Fund of Funds' which helps startups in gaining access to funding, it supports with mechanisms that comprise of online recognition of startups, Startup India Learning Programme, Facilitated Patent filing, Easy Compliance Norms, Relaxed Procurement Norms, incubator support, innovation-focused programmes for students, funding support, tax benefits and addressing of regulatory issues. However, entrepreneurs will need more after the pandemic - owing to a poor and struggling economic ecosystem.

While many governments consider selective tax cuts and subsidies for start-up businesses, which reduce costs of production during the initial months or years of a business, and also consider trade protectionism, which shields nascent industries and upcoming businesses from foreign competition, such measures cannot ensure long-term growth. Subsidies and protectionist policies can make firms too dependent on the government and reduce efficiency as well. Many experts believe that a "growth-oriented" approach is more sustainable. This focuses on the entrepreneurial leadership of these growth firms. It seeks to understand their networks and how to foster the expansion of such networks at the local, national and international level.

Thus, the Indian government and policymakers must consider the strategic intents of the teams running different start-ups. Firms seeking to grow need to be given help in linking up with customers, suppliers and other "actors" within the ecosystem who can provide resources. Such measures would be more effective in increasing entrepreneurship in the long run - in not only the manufacturing sector but other important sectors too.

\section{V.CONCLUSION}

This research has examined the demand and supply patterns in the three core industries of the manufacturing sector in light of the novel coronavirus and has used these patterns and trends, along with important socioeconomic, political and environmental factors to develop measures that could potentially boost the growth of the Indian manufacturing sector and the Indian economy as a whole. However, a lot of questions, and therefore the needs for more research and analysis, remain.

This research-based essay focuses on demand and supply patterns in the national and global markets. However, many other economic factors are potential determinants in the development of the manufacturing sector in the Post-corona world. These factors range from the changes in workplace dynamics to potential changes in production methods and processes. They can have a significant impact on the output and growth of manufacturing activity in India, and subsequently, macroeconomic factors like employment that are influenced by the manufacturing sector. Therefore, these factors also need to be thoroughly analysed and their effects evaluated to provide more complete and informed predictions.

Moreover, the manufacturing sector forms only a part of the real GDP of India; its share in the GDP, as mentioned in the Introduction, is falling. As the service sector expands, and market conditions evolve, the share of manufacturing in the GDP may continue to fall. However, government focus, over the last decade, has nevertheless been centred at the manufacturing sector - as evidenced by the Make-in-India and the recent Aatmanirbhar Bharat initiatives and campaigns. Moreover, many of the socioeconomic and political changes in the manufacturing sector have been favourable for India, and therefore the sector is one that India can capitalise on in the near future. But, unless governmental policies are put into action to boost the manufacturing sector, and unlike recent policies, can create a sustainable economic impact on the sector, any research that goes into the manufacturing sector may potentially become less useful and the economy will fail to capitalise on and leverage the desirable global and national changes in the current scenario and the Post-corona world.

While there may be a lot more research to provide accurate and precise predictions, only one conclusion can be made confidently. It is clear that in the Post-corona world, economies are going to evolve and go under immense change; although predictions and informed suggestions have been put forth, what the future holds for the Indian economy is unknown.

While one can expect healthcare to become increasingly important, e-commerce portals to grow and make great progress, tourism - especially in current coronavirus hotspots to reduce, environmental preservation to possibly be prioritised by many governments, no prediction can be made with absolute certainty. The novel coronavirus is a crisis of unprecedented magnitude, and people and governments across the globe must be fully prepared to suffer losses of such magnitude as well. While governments and global entities are encouraged to utilise their resources in research and development that could potentially save their economies and nations from a great recession, they are also encouraged to invest in ways that could revive not only their manufacturing sector but their economies from the worst possible outcome. After all, what will eventually matter in the future is which people and which nations rise after the impact they suffer from this crisis.

Use

\section{REFERENCES}

[1] "Coronavirus Pandemic: Indian Automobile Sector Could Bear ...." 24 Mar. 2020 https://www.carandbike.com/news/indian-automobile-sector-could-be ar-revenue-loss-of-around-rs-15-000-crores-every-day-2199256.

[2] "Lockdown impact: India April manufacturing PMI at all-time ...." 5 May. 2020 https://m.economictimes.com/news/economy/indicators/indias-factory -activity-slumped-to-record-low-in-april-pmi/articleshow/75527546.c $\underline{\mathrm{ms}}$.

[3] "Manufacturing Sector in India: Market Size, FDI, Govt ...." https://www.ibef.org/industry/manufacturing-sector-india.aspx.

[4] "Role of Manufacturing in Employment Generation in India - IBEF." https://www.ibef.org/download/Role-of-Manufacturing-in-Employme nt-Generation-in-India.pdf.

[5] "indian manufacturing: overview and prospects - IBEF." https://www.ibef.org/download/Indian-Manufacturing-110512.pdf. 


\section{With Changed Market Conditions and Consumer Behavior in the National Economy, How Will the Indian Manufacturing Sector Shape Up in the Post-Corona World?}

[6] "coronavirus impact on IT sector: Coronavirus attack to slow ...." 3 Apr. 2020 , https://economictimes.indiatimes.com/tech/ites/virus-attack-to-slow-d own-it-growth/articleshow/74956507.cms.

[7] "Unemployment rate over 23\% - CMIE." 7 Apr. 2020, https://www.cmie.com/kommon/bin/sr.php?kall=warticle\&dt=2020-0 4-07\%2008:26:04\&msec $=770$.

[8] "Trouble in Motown! Auto sector which is $49 \%$ of manufacturing ...." $30 \quad$ Jul. 2019 https://www.moneycontrol.com/news/business/markets/trouble-in-mot own-auto-sector-which-is-49-of-manufacturing-gdp-looks-for-rescue4264251.html.

[9] "Exclusive: Tens of thousands losing jobs as India's auto crisis ...." 6 Aug. https://www.reuters.com/article/us-india-autos-jobs-exclusive/exclusi ve-tens-of-thousands-losing-jobs-as-indias-auto-crisis-deepens-source s-idUSKCN1UW1XA.

[10] [10] "Why is India's car industry in breakdown mode? - BBC News." 11 Sep. 2019, https://www.bbc.com/news/world-asia-india-49645889.

[11] "Pandemic will cause worst recession since Great ... - Al Jazeera." 9 Apr.

https://www.aljazeera.com/ajimpact/pandemic-worst-recession-greatdepression-imf-200409191924374.html.

[12] "Impact of Bharat Stage-VI norms on Indian Auto \& Auto ...." https://auto.economictimes.indiatimes.com/autologue/impact-of-bhara t-stage-vi-norms-on-indian-auto-auto-component-industry/1543.

[13] "Coronavirus' impact on India's auto sector - The Economic Times." 10 Apr. 2020, https://economictimes.indiatimes.com/markets/stocks/news/coronaviru s-whats-its-impact-on-indias-auto-sector/articleshow/75078607.cms.

[14] "Coronavirus' impact on India's auto sector - The Economic Times." 10 Apr. 2020 https://m.economictimes.com/markets/stocks/news/coronavirus-whatsits-impact-on-indias-auto-sector/articleshow/75078607.cms.

[15] "Impact of COVID-19: 2\% production slowdown in China to ...." 2 Apr.

https://www.financialexpress.com/auto/industry/impact-of-coronaviru s-on-auto-sector-production-slowdown-china-covid19-pandemic/1916 $\underline{987 / .}$.

[16] "Indian auto component industry aims to cut ... - ETAuto." https://auto.economictimes.indiatimes.com/news/auto-components/ind ian-auto-component-industry-aims-to-cut-dependence-on-chinese-imp orts-acma/76546980.

[17] "Covid-19 impact: Automakers want flexible manufacturing for ...." 9 Apr.

https://m.economictimes.com/industry/auto/auto-news/covid-19-impac t-automakers-want-flexible-manufacturing-for-business-after-the-pand emic/articleshow/75065149.cms.

[18] "India Overview - World Bank Group." https://www.worldbank.org/en/country/india/overview.

[19] "Give an account OfAutomobi|e Industry or Software Industry in ...." 17 Jun. 2018, https://brainly.in/question/4226015.

[20] "Netflix | Covid-19: Netflix to reduce traffic on telecom networks ...." $24 \quad$ Mar. 2020 https://m.economictimes.com/tech/internet/covid-19-netflix-to-reducetraffic-on-telecom-networks-by-25-to-mitigate-congestion/articleshow /74786851.cms.

[21] "Indian Firms Dependent On Chinese Inputs Feel The ...." 3 Mar. 2020 ,

https://www.magzter.com/article/Newspaper/The-Hindu-Business-Lin e/Indian-Firms-Dependent-On-Chinese-Inputs-Feel-The-CoronavirusHeat.
[22] "Trade in the time of Coronavirus: Sectors overdependent on ...." 27 Feb. 2020 https://m.economictimes.com/small-biz/sme-sector/trade-in-the-time-o f-coronavirus-sectors-overdependent-on-chinese-imports-face-a-grimreality/articleshow/74312184.cms.

[23] "India Pharma $2020 \quad$ - $\quad$ McKinsey." https://www.mckinsey.com/ /media/mckinsey/dotcom/client_service/ Pharma\%20and\%20Medical\%20Products/PMP\%20NEW/PDFs/7788 86_India_Pharma_2020_Propelling_Access_and_Acceptance_Realisi ng_True_Potential.ashx.

[24] "Coronavirus outbreak: Pharma market grows 9\% in March due ...." 9 Apr. 2020 https://www.business-standard.com/article/companies/panic-buying-a mid-coronavirus-lockdown-helped-pharma-market-grow-9-120040801 570_1.html

[25] "Pharma sector flags shortage of packaging materials, transport." https://www.outlookindia.com/newsscroll/pharma-sector-flags-shortag e-of-packaging-materials-transport/1801206.

[26] "Coronavirus impact on India's pharma sector - The Economic ...." 14 Apr. 2020 https://m.economictimes.com/markets/stocks/news/coronavirus-impac t-on-indias-pharma-sector/articleshow/75136862.cms.

[27] "Approx 13 weeks worth medicines stock in supply chain ...." 13 Apr 2020 , https://www.expresspharma.in/covid19-updates/approx-13-weeks-wor th-medicines-stock-in-supply-chain-pharmatrac-trustock/.

[28] "Why Motilal Oswal's Gautam Duggad Is Worried About FY21 ...." 14 Feb. 2020 https://www.bloombergquint.com/markets/why-motilal-oswals-gauta m-duggad-is-worried-about-fy21-earnings.

[29] "Chemical Companies 'Only Ones' To Benefit From ...." 5 Mar. 2020 https://www.bloombergquint.com/markets/only-chemical-companiesmay-benefit-from-coronavirus-outbreak-says-motilal-oswals-gautam-d uggad.

[30] "Covid-19 pandemic leads to boycott-China sentiment ...." 21 Apr 2020 ,

https://timesofindia.indiatimes.com/home/education/news/covid-19-pa ndemic-leads-to-boycott-china-sentiment-nationalist-upswing-says-du -study/articleshow/75271818.cms.

[31] "India takes another step to block China products with new rules." 23 Jun.

2020

https://www.hindustantimes.com/india-news/india-takes-another-stepto-block-china-products-with-new-rules/story-w4HFrMuTQncPImfbD z39cM.html.

[32] "Japan to Fund Firms to Shift Production Out of China ...." 8 Apr 2020 ,

https://www.bloomberg.com/news/articles/2020-04-08/japan-to-fund-f irms-to-shift-production-out-of-china

[33] "Vestager urges stakebuilding to block Chinese takeovers ...." 12 Apr. 2020 ,

https://www.ft.com/content/e14f24c7-e47a-4c22-8cf3-f629da62b0a7.

[34] "Right Time for India to Collaborate With Foreign Firms as World .... https://onegatemedia.com/2020/04/25/right-time-for-india-to-collabor ate-with-foreign-firms-as-world-moves-away-from-china-says-nitin-ga dkari/.

[35] "Time For Action To Make India Global Manufacturing Hub In ...." 29 Apr. 2020 https://www.medicalbuyer.co.in/time-for-action-to-make-india-globalmanufacturing-hub-in-post-coronavirus-world-industry-experts/.

[36] "Doing Business 2019 - World Bank Group." https://www.worldbank.org/content/dam/doingBusiness/media/Annual -Reports/English/DB2019-report_web-version.pdf.

[37] "Economic Survey 2019-20 - Union Budget." 20 Jan. 2020 https://www.indiabudget.gov.in/economicsurvey/doc/echapter.pdf 
[38] "Renewable Energy Industry in India: Overview, Market Size ...." https://www.ibef.org/industry/renewable-energy.aspx.

[39] "Emerging Markets Outlook 2018. - Climatescope." 27 Nov. 2018, http://global-climatescope.org/assets/data/reports/climatescope-2018-r eport-en.pdf.

[40] "Renewable Energy Industry in India: Overview, Market Size ...." https://www.ibef.org/industry/renewable-energy.aspx.

[41] "Liberal Studies: Vol. 3, Issue 1, January-June 2018." https://books.google.com/books?id=EvbcDwAAQBAJ\&pg=PA45\&lp g=PA45\&dq=As+India+looks+to+meet+its+energy+demand+on+its+ own,+which+is+expected+to+reach+15,820+TWh+by+2040\&source =bl\&ots=hxrTAQJ0Xw\&sig=ACfU3U0ugMqWgUR1vWj1F0A0XC RNjO0pBg\&hl=en.

[42] "Achieving India's Ambitious Renewable Energy Goals: A ...." 12 May. 2017 https://www.wri.org/blog/2017/05/achieving-indias-ambitious-renewa ble-energy-goals-progress-report.

[43] "India plans to add $500 \mathrm{GW}$ renewable energy by 2030 ...." 25 Jun. 2019 ,

https://www.reuters.com/article/us-india-renewables/india-plans-to-ad d-500-gw-renewable-energy-by-2030-government-idUSKCN1TQ1R9

[44] "India Is Taking Steps Forward To Make Use Of Its Extensive ...." 9 Nov. 2019 https://www.climatescorecard.org/2019/11/india-is-taking-steps-forwa rd-to-make-use-of-its-extensive-renewable-energy-resources/.

[45] "Indian oil production falls 5.5\%, and remains nearly 14 ..." 23 Apr. 2020 , https://www.offshore-technology.com/news/indian-oil-production-fall s-5-5-and-remains-nearly-14-below-target/.

[46] "COVID-19 Crisis Will Open up Opportunities for India's ...." 15 Apr. 2020 ,

https://thewire.in/economy/covid-19-india-pharma-opportunities.

[47] "11th India Innovation Summit 2015: Manufacturing ... - India.com." 8 Aug.

https://www.india.com/news/india/11th-india-innovation-summit-201 5-manufacturing-entrepreneurship-crucial-for-make-in-india-495844/.

[48] "Manufacturing entrepreneurship crucial for ... - India Today." 8 Aug. 2015 ,

https://www.indiatoday.in/india/story/make-in-india-manufacturing-en trepreneurship-crucial-287124-2015-08-08.

[49] "What Indian Startups Expect From the Government." 11 Mar. 2019, https://www.entrepreneur.com/article/329951. 